\title{
Maize fine streak virus, a New Leafhopper-Transmitted Rhabdovirus
}

\author{
M. G. Redinbaugh, D. L. Seifers, T. Meulia, J. J. Abt, R. J. Anderson, W. E. Styer, J. Ackerman, \\ R. Salomon, W. Houghton, R. Creamer, D. T. Gordon, and S. A. Hogenhout
}

First author: USDA-ARS, Corn and Soybean Research and Department of Plant Pathology, The Ohio State University, Wooster 44691; second and seventh authors: Kansas State University Agricultural Research Center, Hays 67601; third author: Molecular and Cellular Imaging Center, OARDC, Wooster, OH 44691; fourth and fifth authors: USDA-ARS, Corn and Soybean Research, Wooster, OH 44691; sixth and twelfth authors: Department of Entomology, The Ohio State University, Wooster 44691; eighth author: Volcani Center, BetDagan, Israel; ninth author: Syngenta Seeds, Naples, FL 34114; tenth author: Entomology, Plant Pathology and Weed Science, New Mexico State University, Las Cruces 88003; and eleventh author: Department of Plant Pathology, The Ohio State University, Wooster 44691. Accepted for publication 18 June 2002.

\section{ABSTRACT}

Redinbaugh, M. G., Seifers, D. L., Meulia, T., Abt, J. J., Anderson, R. J., Styer, W. E., Ackerman, J., Salomon, R., Houghton, W., Creamer, R., Gordon, D. T., and Hogenhout, S. A. 2002. Maize fine streak virus, a new leafhopper-transmitted rhabdovirus. Phytopathology 92:1167-1174.

A previously uncharacterized virus was isolated from fall-planted sweet corn (Zea mays L., Syngenta GSS 0966) leaves showing fine chlorotic streaks. Symptomatic plants were negative in enzyme-linked immunosorbent assay against many maize viruses, but reacted weakly with antisera to Sorghum stunt mosaic virus suggesting a distant relationship between the viruses. The virus was readily transmitted by vascular puncture inoculation (VPI), but not by leaf-rub inoculation. Symptoms on maize included dwarfing and fine chlorotic streaks along intermediate and small veins that developed 12 to 17 days post-VPI. The isolated virus was bacilliform (231 $\pm 5 \mathrm{~nm}$ long and $71 \pm 2 \mathrm{~nm}$ wide), with a knobby surface, and obvious helical structure typical of rhabdovirus morphology. Nucleorhabdovirus virions were observed by transmission electron microscopy of infected maize leaf tissue sections. Proteins unique to infected plants were observed in extracts of infected leaves, and the isolated virion contained three proteins with molecular masses $82 \pm 2$, $50 \pm 3$, and $32 \pm 2 \mathrm{kDa}$. Preliminary sequence analysis indicated the virus had similarity to members of the family Rhabdoviridae. The virus was transmitted by Graminella nigrifrons under persistent conditions. The data indicate the virus, provisionally designated Maize fine streak virus, is a new species in the genus Nucleorhabdovirus.

Additional keywords: corn, emerging virus, Maize mosaic virus, virus disease.
Plant rhabdoviruses have complex bacilliform or bullet-shaped virions composed of RNA, protein, and lipid and are transmitted in a persistent manner by aphids, leafhoppers, planthoppers, lacebugs, or mites (17). A number of rhabdoviruses have been found to infect maize (Zea mays L.) worldwide. Of these, Maize mosaic virus (MMV) and Wheat American striate mosaic virus (WASMV) cause disease in North America (17). MMV was first reported in Hawaii and subsequently confirmed in Florida $(5,10)$. However, rhabdovirus-like particles of an unidentified virus were reported in the $1970 \mathrm{~s}$ in maize from other southeastern states (Alabama, Louisiana, Mississippi, and Texas) and Iowa and Nebraska (12).

Because the control of viral diseases requires accurate knowledge of virus properties to develop diagnostic tools and understand factors affecting virus spread, study of emerging viruses in crops is important. In this study, we report on the isolation, culture, and characterization of a previously uncharacterized maize-infecting rhabdovirus from leaf samples obtained from Decatur County in southwestern Georgia that exhibited chlorotic vein streaking. Based on symptoms incited by the virus, it has been provisionally named Maize fine streak virus (MFSV).

Corresponding author: M. G. Redinbaugh; E-mail address: redinbaugh.2@osu.edu

Publication no. P-2002-0826-02R

This article is in the public domain and not copyrightable. It may be freely reprinted with customary crediting of the source. The American Phytopathological Society, 2002.

\section{MATERIALS AND METHODS}

Viral inoculum. Inoculum was prepared by grinding leaf tissue in 5 volumes of $10 \mathrm{mM}$ potassium phosphate, $\mathrm{pH} 7$. Initially, extracts were prepared from field-grown maize leaves that expressed streaks similar to those incited by Maize rayado fino virus (MRFV). Subsequently, inoculum was prepared from symptomatic 'Spirit' sweet corn leaves. Fractions from the purification procedure were used as inoculum. The Hawaiian isolate of MMV was described previously (32) and was maintained by vascular puncture inoculation (VPI) (25). Freeze-dried leaves infected with Maize Iranian mosaic virus (MIMV) (a gift from K. Izadpanah, Shiraz University, Iran), frozen maize leaf extracts containing Sorghum stunt mosaic virus (SSMV), and frozen wheat leaf extracts containing WASMV were used as positive controls for serological experiments.

Pathogen transmission. The virus was maintained in 'Spirit' sweet corn using VPI (25). Mechanical transmission of the virus by leaf-rub inoculation was tested as described for Maize necrotic streak virus (MNeSV) (30). For each test, 5 to 17 seedlings of maize 'Spirit' (six replications), Oh28 (eight replications), Pioneer hybrid 3379 (P3379) (two replications), Triticum aestivum 'Freedom' (six replications), and Sorghum bicolor 'Atlas' (six replications) were inoculated. Soil transmission of the pathogen was tested as previously described (30). Seven replications of 50 kernels per replicate were tested.

Vector transmission. Eight insect species that use maize as a feeding and/or developmental host were chosen to determine the vector range and transmission characteristics of the virus. The corn root aphid Aphis maidis-radicus (Forbes), green peach aphid Myzus persicae (Sulzer), potato aphid Macrosiphum euphorbiae 
(Thomas), and oat bird cherry aphid Rhopalosiphum padi L. from the family Aphididea; corn leafhopper Dalbulus maidis (DeLong and Wolcott) in the tribe Macrostelini, and black-faced leafhopper Graminella nigrifrons (Forbes) and painted leafhopper Endria inimica (Forbes) both in the tribe Deltocephalini from the family Cicadellidae; corn planthopper Peregrinus maidis (Ashmead) from the family Delphacidae; and, western corn rootworm Diabrotica virgifera virgifera (LeConte) from the family Chrysomelidae were tested. Insects were reared and transmission tests were performed as described $(8,30)$.

Seedlings (3- to 5-day old) of maize inbred Oh28 or sweet corn hybrids ('Early Sunglow', 'Seneca Chief', or 'Spirit') were used for vector transmission. Nonpersistent transmission was tested after a 15 min starvation period using a 15 min acquisition-access period (AAP) and 24-h inoculation-access period (IAP) as described (28). For semipersistent transmission, the AAP was 2 days and the IAP 7 days $(26,38)$. Persistent transmission involved an AAP of 7 to 14 days, followed by successive IAP of 7 days each until the insects died $(3,37)$. After the IAP, test plants were fumigated with Vapona for $2 \mathrm{~h}$ to eliminate insects, and then observed for symptom development in greenhouses maintained at $28^{\circ} \mathrm{C}$ (day) and $22^{\circ} \mathrm{C}$ (night) for 28 to 35 days.

Infection of maize germ plasm. Differences in infection rates and symptom expression among maize genotypes after virus inoculation were determined by examining plants for 4 weeks under greenhouse conditions following VPI. The infection rate and area under the disease progress curve (AUDPC) was calculated for three replications of 20 kernels each (29). Significant differences among means were determined using LSD $(\alpha=0.05)$.

Maize lines Hi31 and Hi34 (36) were obtained from J. L. Brewbaker (University of Hawaii, Honolulu) and maintained in Ohio. CML202 and Tzi4 (20) were originally from CIMMYT (Zimbabwe). Pa405 (33), Oh1VI (28), Va35, Oh28, Mo17, and B73 were from our stocks. 'Spirit', VOG134, and GSS 0966 were supplied by Syngenta Seeds Inc. (Boise, ID). Pioneer hybrid 3379 (P3379) was a gift from D. Wilkinson (Pioneer Hi-Bred International, Inc., Johnston, IA), and 'Seneca Chief' was from Seminis Vegetable Seeds (Oxnard, CA).

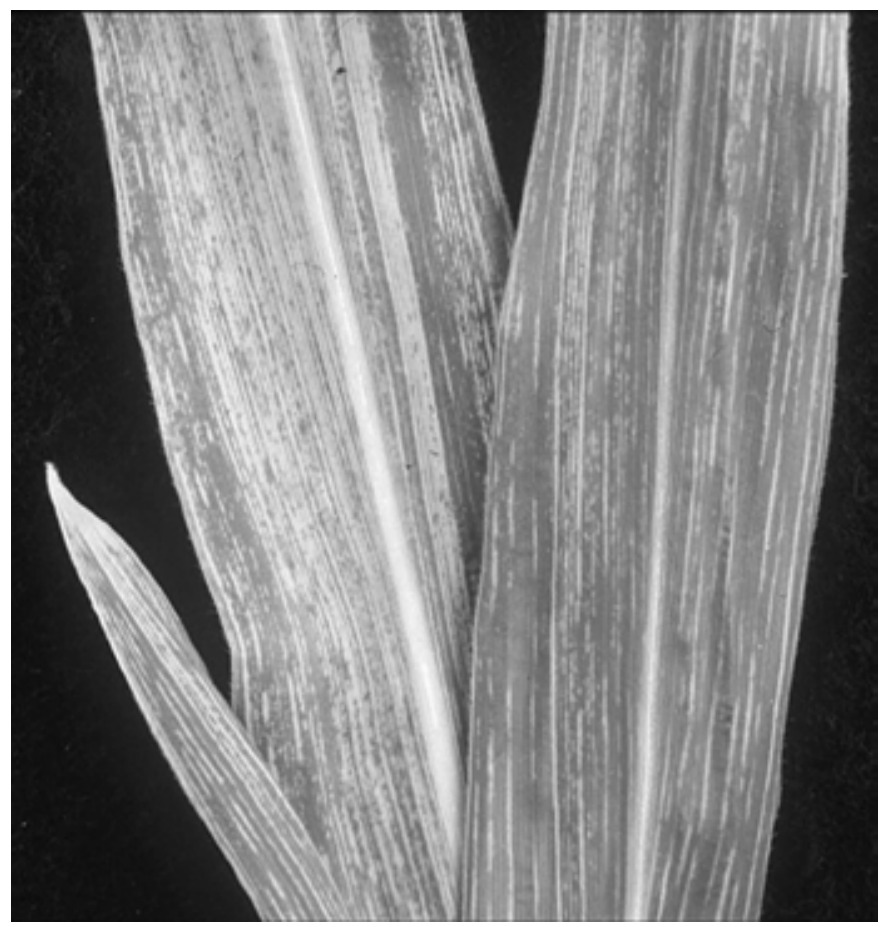

Fig. 1. Sweet corn 'Spirit' 25 days after vascular puncture inoculation with a leaf extract from a plant infected with Maize fine streak virus.
Virus purification and characterization. MFSV was partially purified from maize leaf laminar tissue (26 to 40 days post-VPI) using procedures described by Skaf and Carroll (44) and Creamer (6). Briefly, an extract was prepared in $0.1 \mathrm{M}$ sodium phosphate, pH 7.2, containing $10 \%$ sucrose and treated with activated charcoal (44). After removing the charcoal by centrifugation, the extract was filtered through polyester fiber (Fairfield Corp., Danbury, CT), layered on a $35 \%$ sucrose pad, and centrifuged at $99,000 \times g$ for $30 \mathrm{~min}$. The resulting pellet was resuspended in extraction buffer, and virions were purified on sequential 10 to $40 \%$ and 25 to $50 \%$ sucrose gradients in $0.1 \mathrm{M}$ sodium phosphate, pH 7.2 (6). Purified virions were concentrated by centrifugation $(105,000 \times g$ for $3 \mathrm{~h})$ and resuspended in $1 \mathrm{ml}$ of $25 \mathrm{mM}$ HEPES, $\mathrm{pH} 7.4$, containing $0.15 \mathrm{M} \mathrm{NaCl}$. Protein concentrations were determined using the dye binding method (39).

Electron microscopy. Purified virus samples were placed on 300-mesh formvar and carbon-coated copper grids and negatively stained using $1 \%$ phosphotungstic acid, $\mathrm{pH} 7$. Samples were viewed and photographed with a Philips 201 transmission electron microscope (TEM) at $80 \mathrm{kV}$.

Ultrathin sections were prepared from infected and healthy maize leaf samples. Plant tissue was fixed in 3\% glutaraldehyde, $2 \%$ paraformaldehyde, and $0.1 \mathrm{M}$ sodium phosphate, $\mathrm{pH} 7.2$, at $4^{\circ} \mathrm{C}$ for $16 \mathrm{~h}$, then postfixed for $1 \mathrm{~h}$ in $0.1 \mathrm{M}$ sodium phosphate, $\mathrm{pH} 7.2$, containing $2 \% \mathrm{OsO}_{4}$, dehydrated using a graded ethanol and acetone series, and embedded in Spurr's resin using a 16-h polymerization at $60^{\circ} \mathrm{C}$. Ultrathin sections were counterstained with uranyl acetate and lead citrate and viewed with a Hitachi 7500 TEM.

Minipurification and sodium dodecyl sulfate polyacrylamide gel electrophoresis (SDS-PAGE). Proteins were extracted and purified using the procedure of Lane (22) as modified by Seifers et al. (43). SDS-PAGE (10\% gels) was done according to Laemmli (21), and gels were stained with Commassie Brilliant Blue (CBB) (43). The analyses were conducted three times.

Proteins from purified virions were separated by SDS-PAGE on 4 to $20 \%$ Tris-HCl Ready Gels (BioRad, Richmond, CA) according to the "Ready Gels Application Guide" (Cat. No. 161-0993).

TABLE 1. Response of maize inbreds and hybrids to vascular puncture inoculation with Maize fine streak virus

\begin{tabular}{lcccc}
\hline Maize entry & Resistance $^{\mathrm{w}}$ & \% Infection $^{\mathrm{x}}$ & AUDPC $^{\mathrm{y}}$ & Severity $^{\mathrm{z}}$ \\
\hline P3379 & & $89 \mathrm{a}$ & $1760 \mathrm{a}$ & 2 \\
Spirit & $84 \mathrm{a}$ & $1980 \mathrm{a}$ & 3 \\
Seneca Chief & & $82 \mathrm{a}$ & $1570 \mathrm{ab}$ & 3 \\
B73 & & $80 \mathrm{a}$ & $1530 \mathrm{ab}$ & 2 \\
Early Sunglow & & $79 \mathrm{ab}$ & $1690 \mathrm{a}$ & 3 \\
Mo17 & MNeSV & $78 \mathrm{ab}$ & $1070 \mathrm{bc}$ & 2 \\
Pa405 & Potyviridae & $56 \mathrm{bc}$ & $870 \mathrm{~cd}$ & 2 \\
Oh28 & & $52 \mathrm{c}$ & $1060 \mathrm{bc}$ & 3 \\
Va35 & & $35 \mathrm{~cd}$ & $410 \mathrm{de}$ & 2 \\
GSS 0966 & & $25 \mathrm{de}$ & $310 \mathrm{de}$ & 3 \\
CML202 & MSV & $23 \mathrm{def}$ & $300 \mathrm{de}$ & 1 \\
Tzi4 & MSV & $13 \mathrm{def}$ & $170 \mathrm{e}$ & 3 \\
VOG134 & & $10 \mathrm{ef}$ & $41 \mathrm{e}$ & 2 \\
Oh1VI & MCDV & $1 \mathrm{f}$ & $2 \mathrm{e}$ & 1 \\
Hi31 & MMV & $0 \mathrm{f}$ & $0 \mathrm{e}$ & 0 \\
Hi34 & MMV & $0 \mathrm{f}$ & $0 \mathrm{e}$ & 0 \\
\hline
\end{tabular}

${ }^{\mathrm{w}}$ Maize entries were resistant to the following viruses: MCDV (Maize chlorotic dwarf virus), MMV (Maize mosaic virus), MNeSV (Maize necrotic streak virus), and MSV (Maize streak virus), and the Potyviridae including Maize dwarf mosaic virus, Sugarcane mosaic virus-MDB, and Wheat streak mosaic virus.

Mean percent infection rates for three replications (20 plants per replication) are presented. Means followed by different letters were significantly different $(P>0.05)$.

y Area under disease progress curve (AUDPC). Means followed by different letters were significantly different $(P>0.05)$.

$\mathrm{z}$ The severity rating was based on a scale of 0 (no symptoms) to 3 (severe vein streaking). 
Low Range Molecular Weight Markers (BioRad) were used as standards. After electrophoresis, proteins in the gels were stained with silver (34) or CBB. The analysis was repeated nine times.

Enzyme-linked immunosorbent assay (ELISA) and western blot analyses. Two New Zealand rabbits were immunized with two injections of purified virions $(0.3$ or $0.75 \mathrm{mg}$ of protein per injection) on day 0 , and after 5 weeks ( $0.5 \mathrm{mg}$ of protein) according to a standard protocol (13). The rabbits were bled in weeks 5, 7, 9, and 11 , and antibody titer was determined using the $\mathrm{F}\left(\mathrm{ab}^{\prime}\right)_{2}$-Protein A ELISA as described (30). After 11 weeks, the animals were exsanguinated, and serum was lyopholized and stored at $-20^{\circ} \mathrm{C}$. For assays, leaf tissue was tested using an $\mathrm{F}\left(\mathrm{ab}^{\prime}\right)_{2}$-Protein $\mathrm{A}$ ELISA as described (30), except that $1 \mathrm{mM}$ 2,2-azinobis (3-ethylbenzthiazoline-6-sulfonic acid) and $0.1 \% \mathrm{H}_{2} \mathrm{O}_{2}$ in $0.1 \mathrm{M}$ sodium

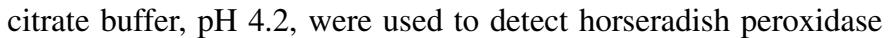
activity. The absorbances at $405 \mathrm{~nm}$ were measured after $20 \mathrm{~min}$ incubation with substrates.

For western blot analysis, leaf protein extracts $(1.75 \mathrm{mg}$ fresh weight) were separated on Ready Gels (BioRad) as described above, transferred to Immobilon-P membranes (Millipore, Inc., Bedford, MA), and probed with virus antisera as described (40). Antisera raised to MFSV (1:2,000 dilution), MMV (1:2,500) (11), MIMV (1:2,000) (15), SSMV (1:2,000) (6), and WASMV $(1: 2,000)$ (42) were used.

Genome characterization. Genome nucleic acid type and size were determined for nucleic acids extracted from purified virions using a modification of the procedure of Milner and Jackson (35). Briefly, purified virions were diluted 10-fold with $10 \mathrm{mM}$ sodium phosphate, $\mathrm{pH} 7.2$, and brought to $0.5 \%$ SDS. After incubation on ice for $45 \mathrm{~min}$, the sample was layered on $10 \mathrm{mM}$ EDTA, pH 7, $5.7 \mathrm{M} \mathrm{CsCl}$ and centrifuged at $100,000 \times g$ at $10^{\circ} \mathrm{C}$ for $16 \mathrm{~h}$. The pellet was resuspended in $500 \mu \mathrm{l}$ of water, precipitated with sodium acetate and ethanol, and resuspended in $11 \mu \mathrm{l}$ of water (41). The RNA concentration was determined using PicoGreen according to the manufacturer's instructions (Molecular Probes, Eugene, OR).

The isolated RNA was used for cDNA synthesis with the Superscript Choice System according to the manufacturer's instructions (Invitrogen Corp., Carlsbad, CA). The cDNAs were ligated into EcoRI-digested, phosphatase-treated pGEM4z (Promega Corp., Madison, WI), and transformed into E. coli TOP10 cells (Invitrogen Corp.). Clones carrying 1.5- (MFSV3GA) and 3-kb (MFSVG6A) inserts that hybridized with a 13-kb RNA in MFSVinfected leaves were selected for sequence analysis. Sequencing was carried out in 550- to 700-bp segments by primer walking using an ABI 3700 DNA Sequence Analyzer and Big Dye Terminator chemistry according to the supplier's instructions (PE Applied

TABLE 2. Insects tested for transmission of Maize fine streak virus

\begin{tabular}{llcccc}
\hline \multirow{2}{*}{ Vector } & \multicolumn{1}{c}{ Family } & Mode $^{\mathrm{w}}$ & $\begin{array}{c}\text { No. of } \\
\text { insects }^{\mathrm{x}}\end{array}$ & Trans $^{\mathrm{y}}$ & $n^{\mathrm{z}}$ \\
\hline Diabrotica virgifera & Chrysomelidae & $\mathrm{N}$ & 15 & $\mathrm{Neg}$ & 1 \\
Myzus persicae & Aphididae & $\mathrm{N}$ & 100 & $\mathrm{Neg}$ & 3 \\
& & $\mathrm{P}$ & 100 & $\mathrm{Neg}$ & 2 \\
Rhopalosiphum padi & Aphididae & $\mathrm{P}$ & 50 & $\mathrm{Neg}$ & 2 \\
Peregrinus maidis & Delphacidae & $\mathrm{P}$ & 200 & $\mathrm{Neg}$ & 4 \\
Dalbulus maidis & Cicadellidae & $\mathrm{P}$ & 200 & $\mathrm{Neg}$ & 2 \\
Endria inimica & Cicadellidae & $\mathrm{S}$ & 50 & $\mathrm{Neg}$ & 2 \\
& & $\mathrm{P}$ & 50 & $\mathrm{Neg}$ & 2 \\
Graminella nigrifrons & Cicadellidae & $\mathrm{S}$ & 200 & $\mathrm{Neg}$ & 2 \\
& & $\mathrm{P}$ & 200 & $\mathrm{Pos}$ & 11 \\
\hline
\end{tabular}

\footnotetext{
${ }^{w}$ The mode of transmission was nonpersistent $(\mathrm{N})$, semipersistent $(\mathrm{S})$, or persistent $(\mathrm{P})$

${ }^{x}$ Number of insects tested per experiment.

y Transmission was scored as positive (pos) if any test plants became symptomatic within the 28 to 35 day observation period. Neg indicates that no plants became symptomatic.

${ }^{\mathrm{z}} n=$ number of independent replications.
}

Biosystems, Foster City, CA). Sequences were analyzed using MacPHRED-MacPHRAP (CodonCode Corp., Dedham, MA). The sequences have been deposited in GenBank with accession numbers AF518001 (MFSVG3A) and AF518002 (the 5' $1.4 \mathrm{~kb}$ of MFSVG6A). The translated cDNA sequences were aligned with rhabdovirus protein sequences using ClustalX (version 1.8, 45). Distances were calculated from the portion of amino acid differences, and trees were constructed using MEGA (19). Alignment gaps were removed from the aligned sequences prior to the distance calculation.

$\mathrm{L}$ protein sequences were obtained by translating the indicated portions of genomic sequences for the following viruses: Bovine ephemeral fever virus (BEFV; 9338-10871 nt of GenBank AF234533), Infectious hematopoietic necrosis virus (IHNV; 57857352 nt of GenBank NC 001652), Mokola virus (MOKV; 63607900 nt of GenBank Y09762), Northern cereal mosaic virus (NCMV; 7513-9044 nt of GenBank AB030277), Rabies virus (RABV; 6335-7875 nt of GenBank RAVMMGN), Rice transitory yellowing virus (RTYV; 8797-10322 nt of GenBank AB011257), Snakehead rhabdovirus (SHRV; 6256-7823 nt of GenBank AF147498), Sonchus yellow net virus (SYNV; 8189-9710 nt of GenBank L32603), Viral hemorrhagic septicemia virus (VHSV; 5822-7389 nt of GenBank NC 000855), Vesicular stomatitis virus Indiana isolate (VSVIN; 5615-7145 nt of GenBank VSVCG), and Vesicular stomatitis virus New Jersey isolate (VSVNJ; 896-2426 nt of GenBank M29788). Ebola virus (EBOV; 12492-14075 nt of GenBank NC 002549) was used as an outgroup.

$\mathrm{N}$ protein sequences were obtained by translating the indicated portions of the genomic sequences for the following viruses: BEFV (51-1378 nt), IHNV (175-1350 nt), Lettuce necrotic yellows virus (LNYV; 79-1450 nt of GenBank L30103), MOKV (49$1491 \mathrm{nt})$, NCMV (142-1437 nt), RABV (59-1482 nt), RTYV (207-1920 nt), SHRV (56-1516 nt), SYNV (47-1697 nt), VHSV (168-1422 nt), and VSVIN (64-1332 nt). EBOV (56-3026 nt) was used as the outgroup.

\section{RESULTS}

In the fall of 1999, leaf samples exhibiting chlorotic vein streaking were obtained from fields near Bainbridge (Decatur County) in southwestern Georgia. Symptoms were widespread in Syngenta Bt hybrid GSS 0966. The plants had fine chlorotic streaks along the major leaf veins similar to symptoms associated with MRFV. Symptomatic leaf material was unreactive in ELISA against antisera to MRFV, Maize dwarf mosaic virus (MDMV), Sugarcane

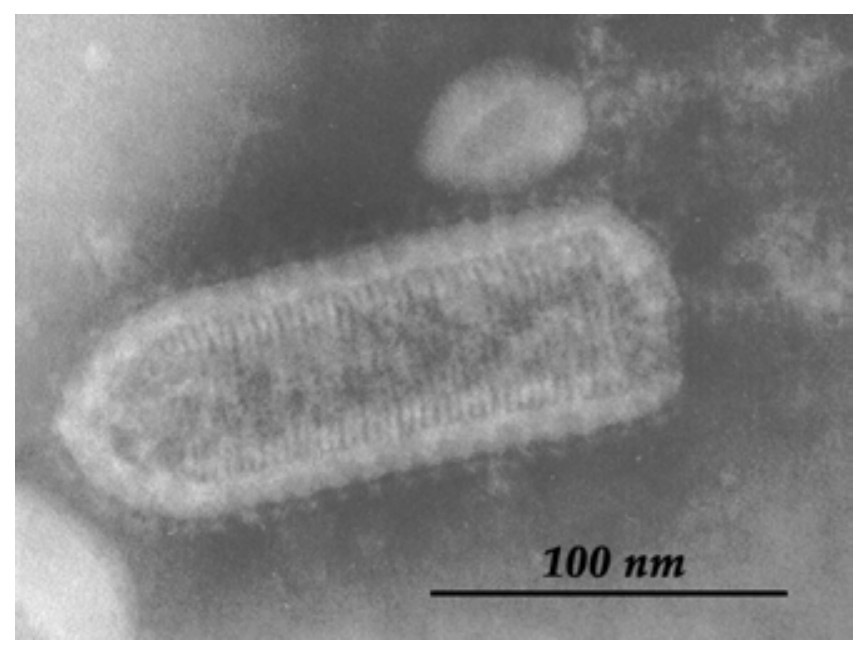

Fig. 2. Ultrastructural analysis of Maize fine streak virus (MFSV). A transmission electron micrograph of purified MFSV negatively stained with phosphotungstic acid. 
mosaic virus-MDB (SCMV-MDB), and Maize chlorotic dwarf virus (MCDV), and bioassay by rub-inoculation was negative (data not shown). Similar symptoms were noted in non-Bt corn, but a much smaller percentage of plants were infected. In 2000, Bt corn was not planted in the area, but symptoms were noted on a small percentage of non-Bt corn plants from which rhabdoviruslike particles were isolated (data not shown). An extract from symptomatic leaves was used to inoculate maize 'Spirit' kernels using VPI. After 14 days, the seedlings showed symptoms similar to those on leaves used for inoculum.

Symptomatology. The first symptoms generally appeared on the second to fourth leaves 10 to 14 days post-VPI. The initial symptoms included chlorotic spots and short streaks on small veins that were unevenly distributed (data not shown). Symptoms were fully developed with continuous streaks on intermediate and small veins, on leaves four to seven, between 3 and 4 weeks postVPI (Fig. 1). The streaks enlarged as the plants matured, such that after approximately 6 weeks post-VPI the leaves appeared white with isolated green spots. Alternatively, some plants showed a partial recovery with only scattered chlorotic spots and streaks on later leaves.

Pathogen transmission. MFSV was transmitted by VPI to several maize inbred and hybrid lines (Table 1). The virus was not mechanically transmitted by leaf-rub inoculation to maize ('Spirit', Oh28, P3379), wheat or sorghum, and no soil transmission of MFSV was observed (data not shown).

MFSV was not transmitted by any of the insects tested under nonpersistent or semipersistent conditions (Table 2). Because electron microscopy indicated the pathogen was a rhabdovirus (described below), vector transmission under persistent conditions was tested with species of the Aphididae, Delphacidae, and Cicadellidae. Transmission by the known maize rhabdovirus vectors $P$. maidis (MMV) and Endria inimica (WAMSV) was unsuccessful. Only the leafhopper, G. nigrifrons, transmitted MFSV. G. nigrifrons also transmitted MFSV to barley (Hordeum vulgare), wheat (Triticum aestivum), oat (Avena sativa), giant foxtail (Seteria faberi), and rye (Secale cereale), but did not transmit the virus to sorghum (Sorghum bicolor 'Atlas') or johnsongrass (Sorghum halpense) (data not shown).

MFSV resistance in maize. All maize lines except Hi31 and Hi34 were infected following VPI, but at significantly different levels (Table 1). The first six entries (starting with P3379) had similar high percentage infections, while the remaining lines were infected at significantly lower levels. It should be noted that, although MFSV did not infect Hi 31 and Hi 34, their infection rates were not different from those of CML202, Tzi4, VOG134, and Oh1VI. Similar, but not identical results were seen for AUDPC data. The severity of symptoms also varied among entries, but was different from infection levels or AUDPCs. For example, while GSS 0966 had a fairly low infection rate, viral symptoms in this hybrid were severe, but some lines with high infection rates had less severe symptoms (P3379 and B73).

Virus purification and Koch's postulates. A diffuse, optically dense band was evident after isobouyant centrifugation of extracts from symptomatic maize leaves. The yield of purified protein was $19 \pm 6 \mu \mathrm{g} / \mathrm{g}$ fresh weight leaf tissue (mean \pm standard error [SE], $n=5$ ). The purified virus preparation contained bullet-shaped or bacilliform particles $231 \pm 5 \mathrm{~nm}$ long and $71 \pm 2 \mathrm{~nm}$ wide (mean \pm SE, $n=14$ ) (Fig. 2). When fractions containing purified virions

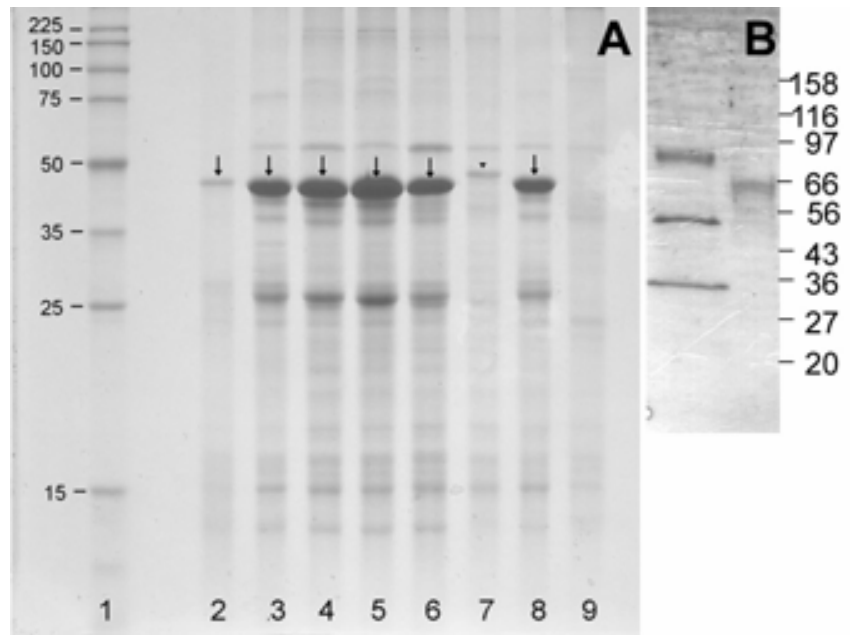

Fig. 4. Analysis of proteins associated with Maize fine streak virus (MFSV). A, Sodium dodecyl sulfate polyacrylamide gel electrophoresis (SDS-PAGE) of crude extracts from leaves infected with MFSV. Soluble proteins were concentrated by minipurification, separated by SDS-PAGE, and stained with Coomassie blue. Lane 1, molecular mass standards (Prosieve Protein Markers, FMC, Philidelphia, PA). The masses (kDa) of the standards are indicated. Lanes 2, 3, and 8 contain extracts of leaves infected with MFSV (2000 isolate). Lanes 5 and 6 contain extracts of leaves infected with MFSV (1999 isolate). Lane 4 contains an extract from a plant inoculated with the extract used in lane 8. Lane 7 contains an extract from a plant infected with Maize mosaic virus (MMV), and lane 9 contains an extract from healthy 'Spirit' corn. Vertical arrows mark position of a protein associated only with symptomatic leaves following serial transfer by vascular puncture inoculation (VPI). The arrow head (lane 7) marks location of a protein associated with MMV propagated in corn by VPI. B, SDS-PAGE of isolated virion proteins. Proteins from $1 \mu \mathrm{g}$ of MFSV virions (left) and $0.15 \mu \mathrm{g}$ of purified MMV (right) are shown. The migration of standard proteins (BioRad low range molecular weight standards) is indicated to the right of the figure.

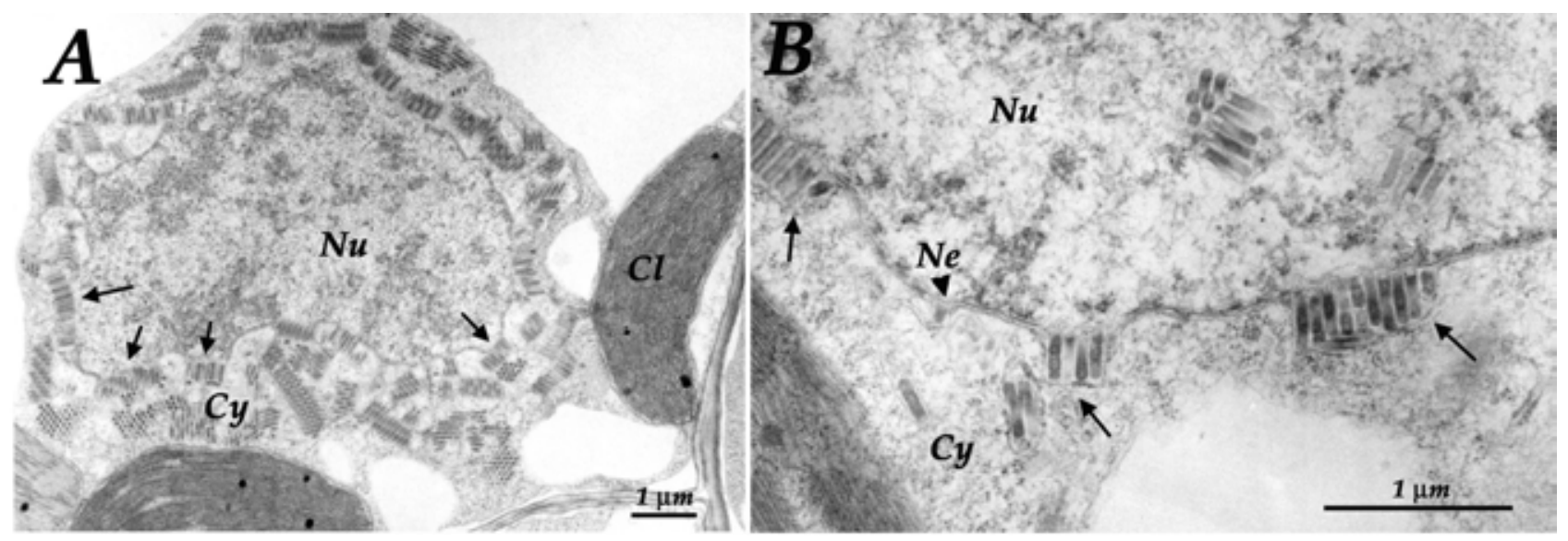

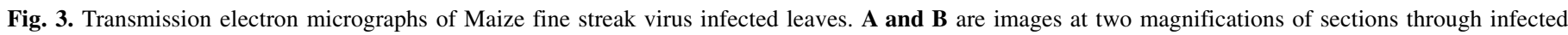

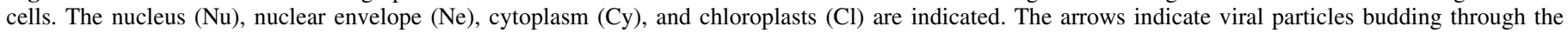
nuclear envelope. 
were used for VPI of 'Spirit' kernels, the inoculated plants were infected at a rate of $71 \pm 7 \%(n=4)$. Virions of the same size and shape as the purified virus were detected in leaves of these infected plants (data not shown).

Leaves from infected plants were examined using TEM, revealing that MFSV was a nucleorhabdovirus (Fig. 3). Viral particles were present in the nucleus (Fig. 3A) and in buds from the perinuclear envelope (Fig. 3B).

Virion proteins. Similar proteins were associated with virus infection for isolates from plants collected in 1999 (Fig. 4A, lanes 5 and 6) and 2000 (Fig. 4A, lanes 2, 3, 4, and 8). The virus-associated proteins of both isolates migrated to different positions in SDS-PAGE than proteins associated with MMV (Fig. 4A, lane 7). Three major protein bands were found after SDS-PAGE of purified MFSV virions (Fig. 4B). The molecular masses of the proteins were $82 \pm 2,50 \pm 3$, and $32 \pm 2 \mathrm{kDa}$ (mean $\pm \mathrm{SD}, n=9$ ).

Serology. The serological relationships among maize-infecting rhabdoviruses were tested using western blot analysis (Fig. 5). Antiserum raised to purified MFSV reacted strongly with five proteins of $80,54,50,36$, and $32 \mathrm{kDa}$ from leaves infected with MFSV. The sizes for three of the proteins correspond with those of the virion proteins seen on SDS-PAGE. The MFSV antiserum did not react with any proteins from MIMV- or MMV-infected leaves nor with any proteins from healthy maize leaves. MMV antiserum reacted strongly only with proteins from MMV-infected leaves, and that for MIMV reacted strongly only with proteins from MIMV-infected leaves. WASMV antiserum did not react with any proteins from the three viruses, indicating there was no serological relationship of WASMV to these three rhabdoviruses. In ELISA, the WASMV antiserum reacted strongly with an extract from wheat leaves infected with WASMV, but not with two different isolates of MFSV (data not shown). Antiserum to SSMV reacted with proteins in all four leaf extracts, and significantly with several proteins from MFSV-infected leaves (Fig. 5). Proteins in frozen extracts from SSMV-infected leaves also reacted with MFSV antisera, although to a lesser extent than proteins from MFSV-infected leaves (data not shown). Thus, MFSV was serologically distinct from MMV, MIMV, and WASMV, but serologically related to SSMV.

Viral genome characterization. A ribonuclease A-sensitive nucleic acid of more than $10 \mathrm{~kb}$ was isolated from purified MFSV (data not shown). No other RNA species was observed in nucleic acid preparations. Two cDNA clones with inserts of $1.5 \mathrm{~kb}$ (MFSV3GA) and $3 \mathrm{~kb}$ (MFSVG6A) hybridized with a large RNA species in total RNA isolated from infected plants, but not from healthy leaves (data not shown). The open reading frame (ORF) encoded by the MFSVG3A cDNA was homologous to the $\mathrm{N}$ terminus of rhabdoviral L proteins (Fig. 6). The MFSVG3A ORF had the highest identity ( 51 to $55 \%$ ) with the plant-infecting nucleorhabdovirus (SYNV and RTYV) and cytorhabdovirus (NCMV) L protein sequences. The MFSV L protein sequence was less similar (43 to $46 \%$ identity) to the mammal-infecting lyssavirus (MOKV and RABV), vesiculovirus (VSV-NJ and VSV-IN), and ephemerovirus (BEFV) sequences, and was least similar $(42 \%$ identity) to the fish-infecting novirabdoviruses (IHNV, SHRV, and VHSV). In phylogenetic analyses, the plant-infecting viruses grouped together with the nucleorhabdoviruses (MFSV, RTYV, and SYNV) forming a strongly supported group (bootstrap value = 100), and MFSV was most closely related to SYNV.

An ORF encoded by the 5' $1.4 \mathrm{~kb}$ of the MFSVG6A cDNA had similarity with the nucleocapsid $(\mathrm{N})$ protein of rhabdoviruses (Fig. 7). The MFSV $\mathrm{N}$ protein had only slightly more identity (44 to $49 \%$ ) with $\mathrm{N}$ protein sequences from plant-infecting rhabdo-

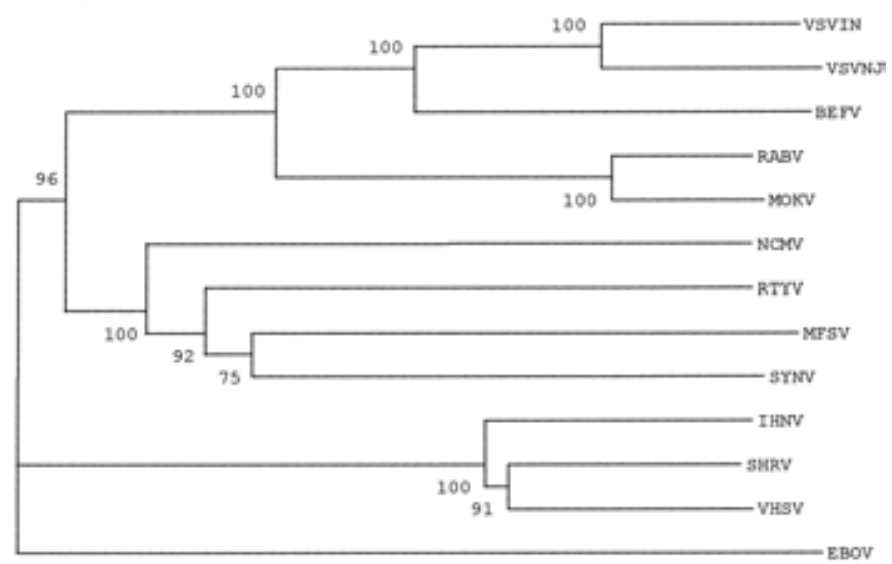

Fig. 6. Phylogenetic analysis of rhabdovirus L protein sequences. The analysis was based on the deduced amino acid sequences of 12 rhabdoviruses and used Ebola virus as the outgroup. The bootstrap confidence levels for 1,000 replications are indicated as percents at the branch points, and the branch lengths are proportional to the distances. The sequences compared include: Bovine ephemeral fever virus, Infectious hematopoietic necrosis virus, Maize fine streak virus, Mokola virus, Northern cereal mosaic virus, Rabies virus, Rice transitory yellowing virus, Snakehead rhabdovirus, Sonchus yellow net virus, Viral hemorrhagic septicemia virus, Vesicular stomatitis virus Indiana isolate, and Vesicular stomatitis virus New Jersey isolate.

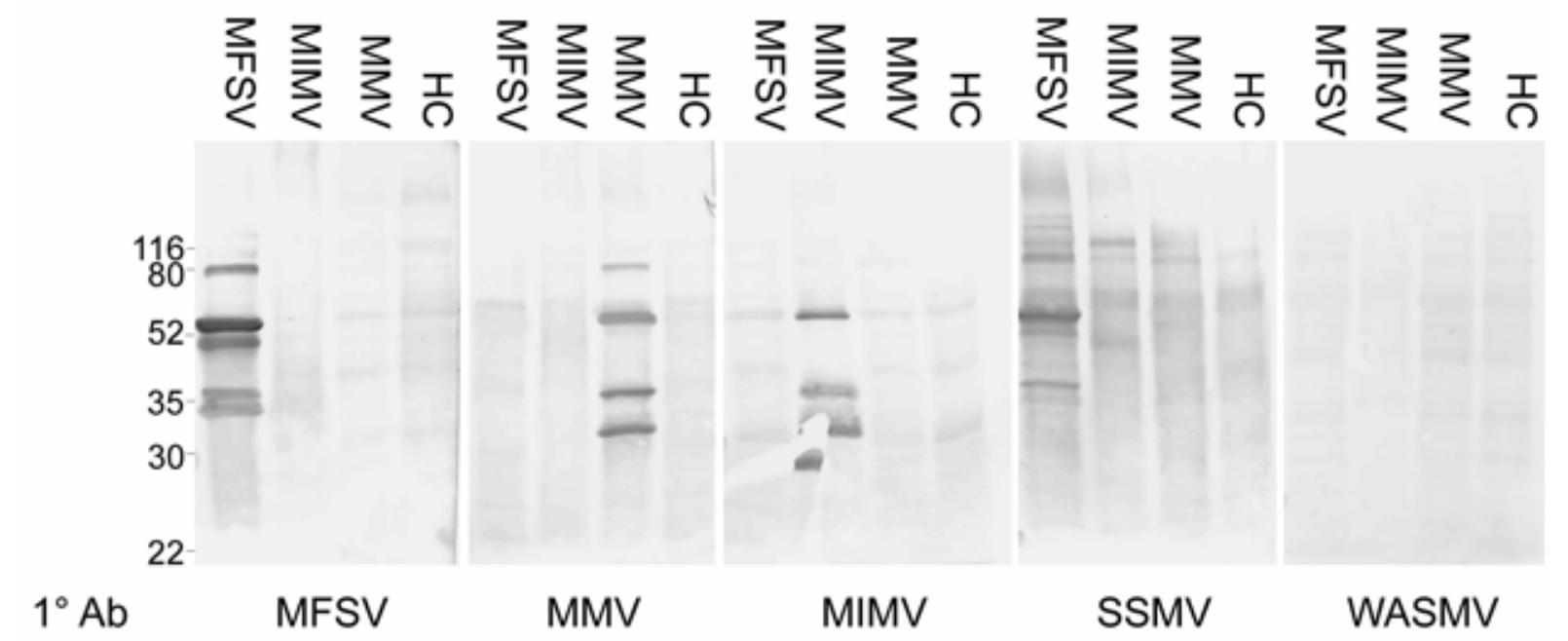

Fig. 5. Western blot analysis of Maize fine streak virus (MFSV), Maize mosaic virus (MMV), and Maize Iranian mosaic virus (MIMV) with antisera raised against maize infecting rhabdoviruses. Antisera to MFSV, MMV, MIMV, Wheat American striate mosaic virus (WASMV), and Sorghum stunt mosaic virus (SSMV) were used. 
viruses than with those from rhabdoviruses infecting mammals (44 to $47 \%$ ) and fish (44 to $45 \%$ ). Although MFSV, RTYV, SNYV, and NCMV formed a strongly supported group in the phylogenetic analysis (Fig. 7), support for a nucleorhabdovirus group was weak (bootstrap value $=57$ ). In addition, one plant-infecting rhabdovirus (LNYV) grouped with the fish-infecting viruses. As with the L protein analysis, the fish- and mammalinfecting viruses formed strongly supported groups.

\section{DISCUSSION}

MFSV could be propagated in maize in the absence of other pathogens, purified, and then transmitted to uninfected maize by

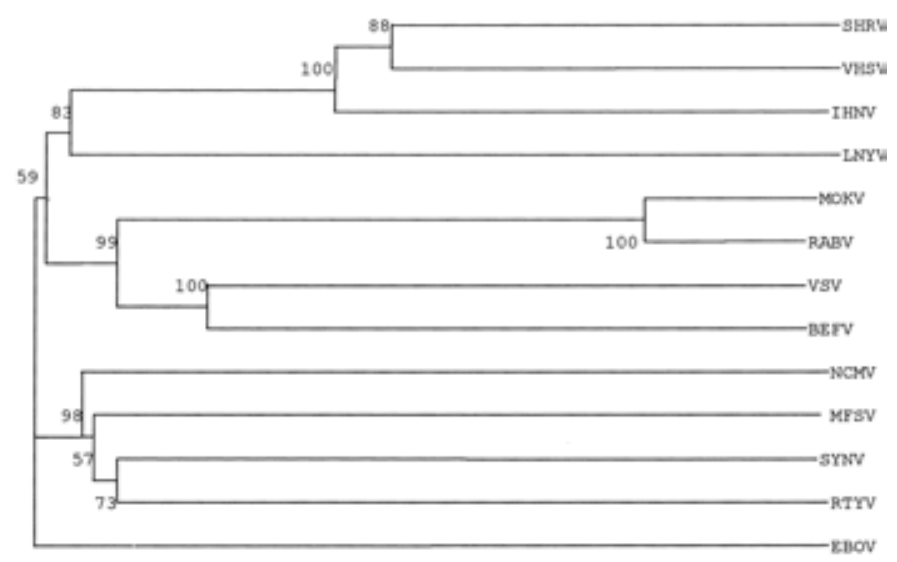

Fig. 7. Phylogenetic analysis for rhabdovirus nucleocapsid protein sequences. The analysis was based on the deduced amino acid sequences of 12 rhabdoviruses and used Ebola virus as the outgroup. The bootstrap confidence levels for 1,000 replications are indicated as percents at the branch points, and the branch lengths are proportional to the distances. The sequences compared include: Bovine ephemeral fever virus, Infectious hematopoietic necrosis virus, Lettuce necrotic yellows virus, Maize fine streak virus, Mokola virus, Northern cereal mosaic virus, Rabies virus, Rice transitory yellowing virus, Snakehead rhabdovirus, Sonchus yellow net virus, Viral hemorrhagic septicemia virus, and Vesicular stomatitis virus Indiana isolate. kernel VPI, fulfilling Koch's postulates. Virus infection incited symptoms similar to those observed in maize naturally infected in the field, and which were similar to, although milder than, those incited by MMV. The proposed name, MFSV, is based on the short chlorotic streaks and spots that occur on small veins of infected maize leaves. The symptomatology, facile transmission by VPI, transmission by $G$. nigrifrons under persistent conditions, particle morphology, and the sequence similarity to rhabdoviral $\mathrm{L}$ and $\mathrm{N}$ protein genes indicate the virus is a member of the family Rhabdoviridae. The presence of virus particles within the maize nucleus, and budding of virions in the perinuclear space indicate MFSV is a member of the genus Nucleorhabdovirus. Several other maize-infecting nucleorhabdoviruses have been described including Cynodon chlorotic streak virus, MMV, MIMV, SSMV, and WASMV $(3,4,17,23,31,32)$. However, a comparison of viral properties (Table 3) suggests that MFSV is a distinct virus species.

Although MMV was reported in Florida $(5,10)$, and MFSV was found in Georgia near the northwest border of Florida, the two viruses are serologically distinct. In addition, MFSV is transmitted by a leafhopper and MMV by a planthopper (14), and the viruses have differently sized virion proteins (Table 3 ). MFSV is similarly different from MIMV, and MIMV has not been detected in the Western Hemisphere (16). Both MFSV and WASMV are transmitted by leafhoppers, including $G$. nigrifrons, and both viruses are found in the United States. (42). However, WASMV has been found only in the northern plains of North America (42). In addition, WASMV virions are larger than and have differently sized virion proteins than those of MFSV $(1,46)$, and the two viruses are serologically distinct.

The reactions of MFSV and SSMV with antisera raised against the two viruses indicate a serological relationship between these two viruses. However, in contrast to MFSV, SSMV was not transmitted by G. nigrifrons (7). G. nigrifrons did not transmit MFSV to 'Atlas' sorghum or johnsongrass, although the leafhopper uses Sorghum species as feeding hosts (24). Further, SSMV has not been reported outside of California (7,31). As indicated in Table 3, the sizes of virion proteins for SSMV (6) are larger than those for MFSV. While comparison of virus transmission by G. sonora and

TABLE 3. Properties of some maize infecting rhabdoviruses

\begin{tabular}{|c|c|c|c|c|c|c|}
\hline Virus $^{\mathrm{w}}$ & Vectors $^{\mathrm{x}}$ & Nonvectors $^{\mathrm{y}}$ & Virion size $(\mathrm{nm})$ & Virion proteins $(\mathrm{kDa})$ & Distribution $^{z}$ & References \\
\hline MFSV & Graminella nigrifrons & $\begin{array}{l}\text { Peregrinus maidis } \\
\text { Endria inimica } \\
\text { Dalbulus maidis }\end{array}$ & $231 \times 71$ & $\begin{array}{l}82 \\
50 \\
32\end{array}$ & Georgia & This paper \\
\hline SSMV & G. sonora & $\begin{array}{l}\text { G. nigrifrons } \\
\text { P. maidis }\end{array}$ & $218 \times 70$ & $\begin{array}{l}91 \\
59 \\
36 \\
30\end{array}$ & California & $6,7,31$ \\
\hline
\end{tabular}

$\overline{{ }^{\mathrm{M}} \mathrm{MFSV}}=\mathrm{Maize}$ fine streak virus, MMV $=$ Maize mosaic virus, MIMV = Maize Iranian mosaic virus, $\mathrm{SSMV}=$ Sorghum stunt mosaic virus, and WASMV $=$ Wheat American striate mosaic virus.

${ }^{\mathrm{x}}$ Insects demonstrated to be vectors under persistent transmission conditions.

${ }^{y}$ Insects demonstrated not to be vectors under persistent transmission conditions.

${ }^{\mathrm{z}}$ Areas where the virus has been reported. 
G. nigrifrons would be useful to fully differentiate between MFSV and SSMV, the lack of an available isolate of SSMV prevents side-by-side comparison of the viruses. Nonetheless, the current data suggest that MFSV is a new maize-infecting rhabdovirus distinct from, but related to, SSMV.

The known vectors of maize-infecting rhabdoviruses include planthoppers and leafhoppers (Table 3). MFSV was transmitted by $G$. nigrifrons, but not by the two leafhoppers (E. inimica and $D$. maidis) that vector other maize-infecting rhabdoviruses, and MFSV was not transmitted by $P$. maidis, the planthopper vector of MMV. Such specificity is not unusual among maize-infecting rhabdoviruses. For example, MIMV is transmitted by Ribautodelphax notabilis planthoppers, but not by $P$. maidis (16). In addition, SSMV transmission is species specific, with $G$. sonora being a vector, but not $G$. nigrifrons (7). The molecular and biochemical bases for this high degree of vector specificity remain to be determined.

The preliminary sequence information indicates that MFSV is a member of the family Rhabdoviridae, and that the three nucleorhabdoviruses for which $\mathrm{L}$ protein gene sequences are available (RTYV, SYNV, and MFSV) are more closely related to each other than they are to the cytorhabdovirus, NCMV. Analysis of rhabdoviral $\mathrm{N}$ proteins also indicated a close relationship among plantinfecting rhabdoviruses. In this analysis, groups containing the mammal-infecting and fish-infecting viruses were strongly supported, similarly to a previous analysis (9). However, the phylogenetic relationships among these groups of viruses are not clear. One problem is that there are very few complete genome sequences available for the insect- and plant-infecting rhabdoviruses. More sequence information from different groups of rhabdoviruses will be required to gain a good understanding of rhabdovirus evolution and molecular relationships between the viruses and their insect vectors.

Whenever a new virus is described, questions regarding its agronomic importance and reasons for emergence arise. In the case of MFSV, the virus has been found only in limited areas of southwestern Georgia in two fall-growing seasons, suggesting the virus is currently of limited agronomic importance. However, the maize collected in 1999 that resulted in the original isolation of MFSV was thought to be infected by SCMV-MDB. Because incorrect visual diagnosis of viral symptoms in maize could lead to underestimation of MFSV incidence, the distribution of the virus may be much greater than the areas identified in 1999 and 2000. MFSV may have emerged because of recent changes in agronomic practices for sweet corn. The virus was observed in fallplanted insect-resistant Bt sweet corn. Because the Bt-sweet corn was not sprayed to control fall armyworms and earworms, $G$. nigrifrons might have infested the fields and transmitted the virus. G. nigrifrons is present in most of the eastern half of the United States (18), raising the potential that MFSV may have a wide occurrence. Because maize inbreds carrying resistance to MMV showed reduced levels of MFSV infection by VPI, some of the hybrid corn grown in the southeastern United States may already carry a degree of resistance to the virus. However, more work to determine the influence of the vector on MFSV infection of maize germ plasm is required before a definitive answer about resistance can be provided. The cornbelt germ plasm tested, particularly inbreds B73 and Mo17, were easily infected by VPI and apparently carry little resistance to MFSV. The serological and molecular diagnostic tools developed in this study will be useful for determining the virus' distribution in maize and other hosts.

\section{ACKNOWLEDGMENTS}

This work is a cooperative investigation of USDA-ARS, OSU, and the OARDC, Wooster. Salaries and support provided by state and federal funds were appropriated to OSU-OARDC, Wooster. Mention of a trademark, proprietary product, trade names or commercial products in this article is solely for the purpose of providing scientific information; it does not constitute a guarantee, warranty, recommendation, or endorsement by the USDA and does not imply approval to the exclusion of other products that also may be suitable. We thank K. J. Willie, J. D. Vacha, J. C. M. Todd, and D. E. Fulton for invaluable technical assistance.

\section{LITERATURE CITED}

1. Amhed, M. E., Sinha, R. C., and Hochster, R. M. 1970. Purification and some morphological characters of wheat striate mosaic virus. Virology 41:768-771.

2. Ammar, E. D., Gomez-Luengo, R. G., and Gordon, D. T. 1987. Cytopathology and sites of rhabdovirus assembly and accumulation for Iranian (Shiraz) maize mosaic virus infected maize. (Abstr.) Phytopathology 77:1732.

3. Ammar, E. D., and Nault, L. R. 1985. Assembly and accumulation sites of Maize mosaic virus in its planthopper vector. Intervirology 24:33-41.

4. Bradfute, O. E., and Robertson, D. C. 1974. Rhabdovirus-like particles in stunted maize from Texas and Hawaii. Proc. Electron Microsc. Soc. Am. 32:266-267.

5. Bradfute, O. E., and Tsai, J. H. 1983. Identification of maize mosaic virus in Florida. Plant Dis. 67:1339-1342.

6. Creamer, R. 1992. Purification and protein characterization of sorghum stunt mosaic rhabdovirus. Phytopathology 82:1473-1476.

7. Creamer, R., He, X., and Styer, W. E. 1997. Transmission of sorghum stunt mosaic rhabdovirus by the leafhopper vector, Graminella sonora (Homoptera: Cicadellidae). Plant Dis. 81:63-65.

8. D'Arcy, C. J., and Nault, L. R. 1982. Insect transmission of plant-viruses and mycoplasma-like and Rickettsia-like organisms. Plant Dis. 66:99-104.

9. Dhillon, J., Cowley, J. A., Wang, Y. H., and Walker, P. J. 2000. RNA polymerase (L) gene and genome terminal sequences of ephemeroviruses bovine ephemeral fever virus and Adelaide River virus indicate a close relationship to vesiculoviruses. Virus Res. 70:87-95.

10. Falk, B. W., and Tsai, J. H. 1983. Physicochemical characterization of maize mosaic virus. Phytopathology 73:1536-1539.

11. Gomez-Luengo, R. G., and Gordon, D. T. 1987. Comparison of proteins and serological reactions of three isolates of maize mosaic virus with those of the Iranian (Shiraz) maize mosaic virus. (Abstr.) Phytopathology 77:1705.

12. Gordon, D. T., Bradfute, O. E., Gingery, R. E., Knoke, J. K., Nault, L. R., and Scott, G. E. 1981. Introduction: History, geographical distribution, pathogen characteristics and economic importance. Pages 1-18 in: Virus and Virus-Like Diseases of Maize in the United States. D. T. Gordon, J. K. Knoke, and G. E. Scott, eds. Ohio Agric. Res. Dev. Cent. Wooster, $\mathrm{OH}$.

13. Harlow, E., and Lane, D. 1988. Antibodies: A Laboratory Manual. Cold Spring Harbor Laboratory Press, Cold Spring Harbor, NY.

14. Herold, F. 1960. Estudios sobre dos enfermedades virales del maíz en Venzuela. Acta Cient. Venez. (suppl. 1):221-227

15. Izadpanah, K. 1989. Purification and serology of the Iranian maize mosaic rhabdovirus. J. Phytopathol. 126:43-50.

16. Izadpanah, K., Ahmadi, A. A., Parvin, S., and Jafari, S. A. 1983. Transmission, particle-size and additional hosts of the rhabdovirus causing maize mosaic in Shiraz, Iran. J. Phytopathol. 107:283-288.

17. Jackson, A. O., Milbrath, G. M., and Jedlinski, H. 1981. Rhabdovirus diseases of the Gramineae. Pages 51-76 in: Virus and Virus-Like Diseases of Maize in the United States. D. T. Gordon, J. K. Knoke, and G. E. Scott, eds. Ohio Agric. Res. Dev. Cent. Wooster, OH.

18. Kramer, J. P. 1967. A taxonomic study of Graminella nitrifrons, a vector of corn stunt disease, and its congeners in the United States (Homoptera: Cicadellidae: Deltocephalinae). Ann. Entomol. Soc. Am. 60:604-616.

19. Kumar, S., Tamura, K., and Nei, M. 1993. MEGA: Molecular evolutionary genetics analysis. Institute of Molecular Evolutionary Genetics. University Park, PA.

20. Kyetere, D. T., Ming, R., McMullen, M. D., Pratt, R. C., Brewbaker, J., and Musket, T. 1999. Genetic analysis of tolerance to maize streak virus in maize. Genome 42:20-26.

21. Laemmli, U. K. 1970. Cleavage of structural proteins during the assembly of the head of bacteriophage T4. Nature 227:680-685.

22. Lane, L. C. 1986. Propagation and purification of RNA plant viruses. Methods Enzymol. 118:687-696.

23. Lockhart, B. E. L., Khaless, N., Elmaataoui, M., and Lastra, R. 1985. Cynodon chlorotic streak virus, a previously undescribed plant rhabdovirus infecting bermuda grass and maize in the Mediterranean area. Phytopathology 75:1094-1098.

24. Lopes, J. R. S., Nault, L. R., and Gingery, R. E. 1994. Leafhopper transmission and host-plant range of Maize chlorotic dwarf waikavirus strains. Phytopathology 84:876-882.

25. Louie, R. 1995. Vascular puncture of maize kernels for the mechanical 
transmission of maize white line mosaic virus and other viruses of maize. Phytopathology 85:139-143.

26. Louie, R., and Anderson, R. J. 1993. Evaluation of Maize chlorotic dwarf virus resistance in maize with multiple inoculations by Graminella nigrifrons (Homoptera, Cicadellidae). J. Econ. Entomol. 86:1579-1583.

27. Louie, R., Jones, M. W., Anderson, R. A., and Redinbaugh, M. G. 2002. Notice of release of Oh1VI. Crop Sci. 42:991.

28. Louie, R., and Knoke, J. K. 1975. Strains of maize dwarf mosaic virus. Plant Dis. Rep. 59:518-522.

29. Louie, R., Knoke, J. K., and Findley, W. R. 1990. Elite maize germplasm-reactions to maize dwarf mosaic and maize chlorotic dwarf viruses. Crop Sci. 30:1210-1215.

30. Louie, R., Redinbaugh, M. G., Gordon, D. T., Abt, J. J., and Anderson, R. J. 2000. Maize necrotic streak virus, a new maize virus with similarity to species of the family Tombusviridae. Plant Dis. 84:1133-1139.

31. Mayhew, D. E., and Flock, R. A. 1981. Sorghum stunt mosaic. Plant Dis. 65:84-86.

32. McDaniel, L. L., Ammar, E. D., and Gordon, D. T. 1985. Assembly, morphology, and accumulation of a Hawaiian isolate of maize mosaicvirus in maize. Phytopathology 75:1167-1172.

33. McMullen, M. D., and Louie, R. 1989. The linkage of molecular markers to a gene controlling the symptom response in maize to maize dwarf mosaic virus. Mol. Plant-Microbe Interact. 2:309-314.

34. Merril, C. R., Goldman, D., and Van Keuren, M. L. 1983. Simplified silver protein detections and image enhancement methods in polyacrylamide gels. Electrophoresis 3:17-23.

35. Milner, J. J., and Jackson, A. O. 1979. Sequence complimentarity of Sonchus yellow net virus with RNA isolated from the polysomes of infected tobacco. Virology 97:90-99.

36. Ming, R., Brewbaker, J. L., Pratt, R. C., Musket, T. A., and McMullen, M. D. 1997. Molecular mapping of a major gene conferring resistance to maize mosaic virus. Theor. Appl. Genet. 95:271-275.

37. Nault, L. R. 1980. Maize bushy stunt and corn stunt-A comparison of disease symptoms, pathogen host ranges, and vectors. Phytopathology 70:659-662.

38. Nault, L. R., Styer, W. E., Knoke, J. K., and Pitre, H. N. 1973. Semipersistent transmission of leafhopper-borne Maize chlorotic dwarf virus. J. Econ. Entomol. 66:1271-1273.

39. Redinbaugh, M. G., and Campbell, W. H. 1985. Adaptation of the dyebinding protein assay to microtiter plates. Anal. Biochem. 147:144-147.

40. Redinbaugh, M. G., and Campbell, W. H. 1998. Nitrate regulation of the oxidative pentose phosphate pathway in maize (Zea mays L.) root plastids: Induction of 6- phosphogluconate dehydrogenase activity, protein and transcript levels. Plant Sci. 134:129-140.

41. Sambrook, J., Fritsch, E. F., and Maniatis, T. 1989. Molecular Cloning: A Laboratory Manual. Cold Spring Harbor Laboratory Press, Cold Spring, Harbor, NY.

42. Seifers, D. L., Harvey, T. L., and Bowden, R. L. 1995. Occurrence and symptom expression of American wheat striate mosaic virus in wheat in Kansas. Plant Dis. 79:853-858.

43. Seifers, D. L., Harvey, T. L., Kofoid, K. D., and Stegmeier, W. D. 1996. Natural infection of pearl millet and sorghum by wheat streak mosaic virus in Kansas. Plant Dis. 80:179-185.

44. Skaf, J. S., and Carroll, T. W. 1995. Purification of barley yellow streak mosaic virus and detection by DAS-ELISA and ISEM using polyclonal antibodies. Plant Dis. 79:1003-1007.

45. Thompson, J. D., Gibson, T. J., Plewniak, F., Jeanmougin, F., and Higgins, D. G. 1997. The ClustalX windows interface: Flexible strategies for multiple sequence alignment aided by quality analysis tools. Nucleic Acids Res. 24:4876-4882.

46. Trefzger-Stevens, J., and Lee, P. E. 1977. The structural proteins of wheat striate mosaic virus, plant rhabdovirus. Virology 78:144-149. 